\title{
c. \\ A Deletion Upstream of SOX10 Causes Light Yellow Plumage Colour in Chicken
}

\author{
Tao Zhu ${ }^{1,+}{ }^{\mathbb{D}}$, Mengchao Liu ${ }^{2,+}$, Shan Peng ${ }^{3}$, Xinye Zhang ${ }^{1}$, Yu Chen ${ }^{4}$, Xueze Lv ${ }^{4}$, Weifang Yang ${ }^{4}$, Kaiyang $\mathrm{Li}^{4}$, \\ Jianwei Zhang ${ }^{4}$, Huie Wang ${ }^{5}$, Haiying $\mathrm{Li}^{6}$, Zhonghua Ning ${ }^{1}$, Liang Wang ${ }^{3}$ and Lujiang $\mathrm{Qu}{ }^{1, *}$
}

1 National Engineering Laboratory for Animal Breeding, Department of Animal Genetics and Breeding, College of Animal Science and Technology, China Agricultural University, Beijing 100193, China; zhutao@cau.edu.cn (T.Z.); Leaf_zxy@outlook.com (X.Z.); ningzhh@cau.edu.cn (Z.N.)

2 Beijing Municipal Bureau of Agriculture and Rural Affairs, Beijing 100005, China; 13811000113@163.com

3 Guiyang Municipal General Station of Animal Science, Guizhou 550081, China; december_sky@163.com (S.P.); xqcpjcs@163.com (L.W.)

4 Beijing Municipal General Station of Animal Science, Beijing 100107, China; chenyu.cncn@163.com (Y.C.); lvxueze0310@163.com (X.L.); carspstp@126.com (W.Y.); likaiyanga@163.com (K.L.); zjw7432@126.com (J.Z.)

5 College of Animal Science, Tarim University, Alar 843300, China; whedky@126.com

6 College of Animal Science, Xinjiang Agricultural University, Urumchi 830000, China; lhy-3@163.com

* Correspondence: quluj@cau.edu.cn

+ These authors contributed equally to this work.

check for updates

Citation: Zhu, T.; Liu, M.; Peng, S.; Zhang, X.; Chen, Y.; Lv, X.; Yang, W.; Li, K.; Zhang, J.; Wang, H.; et al. A Deletion Upstream of SOX10 Causes Light Yellow Plumage Colour in Chicken. Genes 2022, 13, 327. https:// doi.org/10.3390/genes13020327

Academic Editor: Jacqueline Smith

Received: 7 December 2021

Accepted: 7 February 2022

Published: 10 February 2022

Publisher's Note: MDPI stays neutral with regard to jurisdictional claims in published maps and institutional affiliations.

Copyright: (C) 2022 by the authors. Licensee MDPI, Basel, Switzerland. This article is an open access article distributed under the terms and conditions of the Creative Commons Attribution (CC BY) license (https:// creativecommons.org/licenses/by/ $4.0 /)$.

\begin{abstract}
Chicken plumage colour is a complex trait controlled by many genes. Herein, through Rhode Island Red (RIR) and White Leghorn (WL) F1 cross populations, the segregation of plumage color was observed in females, showing white in males, and dark red (DR) and light yellow (LY) in females. The white has been found to be caused by dominant white alleles $(I)$ and the DR phenotype is attributed to a sex-linked recessive silver allele $(S * S)$. LY is a derived feather colour phenotype and the genetic mechanism of this is unclear. In order to explore the genetic basis for LY, we randomly selected 40 DR and 39 LY chickens for paired-end sequencing. Through the use of association analysis, we found the LY phenotype is caused by a $7.6 \mathrm{~kb}$ non-coding deletion near the SOX10 gene. This mutation has been reported to be responsible for dark brown plumage in chicken, and subsequent diagnostic PCR tests showed that the length of the long-range non-coding deletion is $7.6 \mathrm{~kb}$ instead of $8.3 \mathrm{~kb}$ as previously reported.
\end{abstract}

Keywords: chicken; SOX10 gene; plumage colour; pigmentation; genome wide association study

\section{Introduction}

Chickens were domesticated from the ancestral red jungle fowl (Gallus gallus), which are globally distributed as a source of eggs and meat for humans [1-4]. The long domestication history has led to many variants in the chicken genome, along with considerable phenotypic alterations. Compared to their wild ancestor, the domesticated chickens present various plumage colours and excellent production traits, with numerous breeds produced to meet human needs [5-7]. Previous studies have shown that plumage colour is related to the content of eumelanin and melatonin [8,9]. Melanocytes in hair follicles are the source of pigment in feathers. While eumelanin appears black and melatonin is brown, both melatonin and eumelanin are the derivatives of tyrosine [10,11]. Pigment synthesis pathways are complex and involve a large number of enzymes, with many genes reported to be related to abnormal pigment synthesis [12-14]. Both autosomal and sex chromosomes have been found to contain genes that cause plumage colour variations. PMEL17 was identified to be the dominant white $(I)$ gene and present in White Leghorn (WL) as homozygote [15]. The sex-linked Silver $(S * S)$ phenotype is attributed to SLC45A2 and the Rhode Island Red (RIR) has the homozygous recessive allele $(S * N)$ [16]. MC1R is associated with feather 
pigmentation in many studies [17-19]. Sex-linked barring and dark brown feather colours are genetically decided by CDKN2A and SOX10, respectively [20,21].

In this study, besides the dominant white, the other two plumage colours, dark red (DR) and light yellow (LY), were observed in a RIR/WL cross population in females (Figure 1). Genome wide association study (GWAS) was performed to identify causative mutations for the colour variation. The results suggested that the SOX10 gene is responsible for the feather colour variation; however, no non-synonymous mutations were identified in the SOX10 gene. Instead, the sequencing depth differences between colour variants suggested that there is a structural variant upstream of the SOX10 gene. PCR shows a $7.6 \mathrm{~kb}$ deletion in LY chickens that is potentially causative for the LY variation.
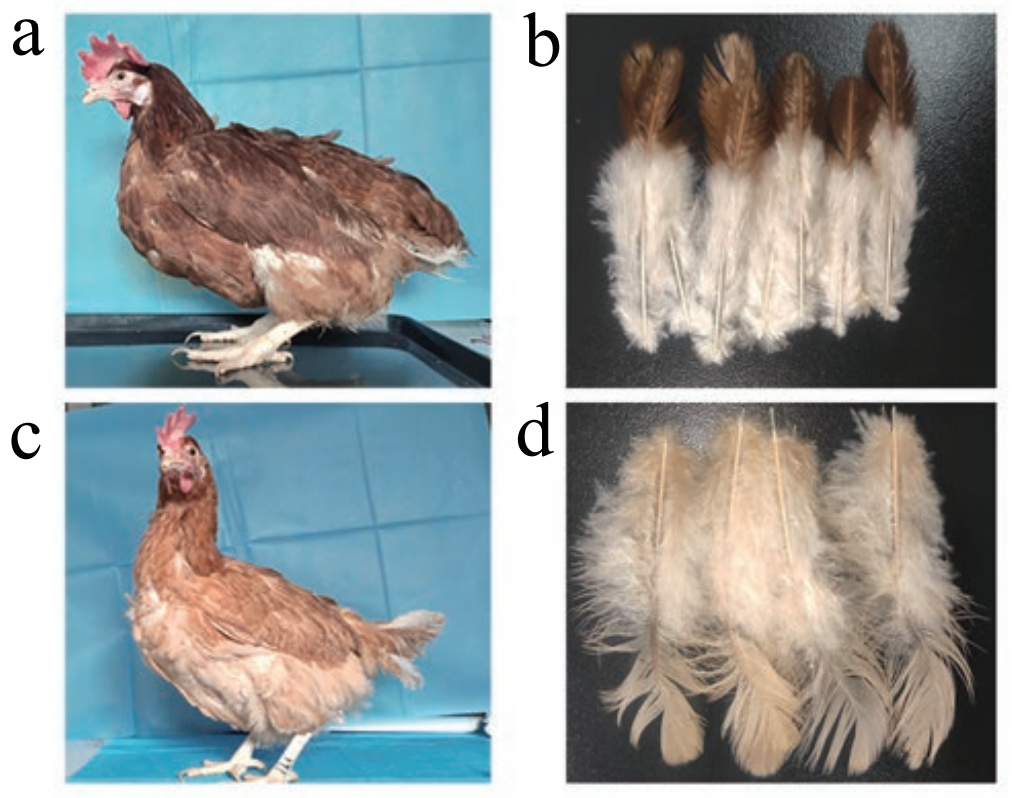

Figure 1. Images of chicken plumage colour patterns. (a) Deep red (DR) plumage. (b). The neck feathers of DR chicken. (c) Light yellow (LY) plumage. (d) The neck feathers of LY chicken.

\section{Materials and Methods}

We generated an F1 generation for gene mapping by crossing 100 RIR males and $2000 \mathrm{WL}$ females. The intercross females showed obvious plumage colour phenotype segregation, including DR and LY, while male showed white feathers. In females, contour feathers are dark red(DR) on the surface and white for the fluff, while the contour feathers of LY chickens are all light yellow for both surface and fluff (Figure 1). In order to study the plumage variation in females, we randomly selected 40 DR and 39 LY hens for pairedend sequencing.

Blood samples were collected from ulnar veins using EDTA as an anticoagulant. DNA was extracted by TIANamp Blood DNA Kit (TIANGEN BIOTECH, Beijing, China) according to the manufacturer's instructions. Whole genome sequencing was performed on an Illumina 2500 platform with $5 \mathrm{X}$ average coverage. The raw data were filtered by fastp with default parameters [22]; then, the clean data were mapped to the chicken genome (GRCg6a, GCA_000002315.5) by BWA and SAMtools [23,23]. GATK3.6 and Picard (http:/ / broadinstitute.github.io/picard/, accessed on 27 April 2016) were then used to call and filter variants [24]. SNPs were filtered using the following rules: (a) QUAL > 30.0; (b) QD > 5.0; (c) FS < 60.0; (d) MQ > 40.0; (e) MQRankSum > -12.5; and (f) ReadPosRankSum > -8.0. Additionally, if there were more than 3 SNPs clustered in a $10 \mathrm{bp}$ window, all 3 SNPs were considered as false positives and removed. The variant file was converted to plink format by VCFtools [25], and SNPs with a call rate lower than 0.8 were removed. Case-control 
GWAS was then performed using plink [26]. The significance threshold was set at $-\log 10$ $(0.05 /$ number of variants).

The sequencing data showed that a deletion upstream of the SOX10 gene may be responsible for the LY plumage colour in hens. The primers F: TTTGCTCCCAACCCCTCATC and R: AGCCATCGGAAAAGAAGCCA were used to amplify the chromosome 1 (GRCg6a) region from 51,034,587 bp to 51,043,419 bp, which overlapped the deletion. PCR was performed in a total volume of $25 \mu \mathrm{L}$ containing $1 \mu \mathrm{L}$ DNA $(50 \mathrm{ng} / \mu \mathrm{L}), 12.5 \mu \mathrm{L} \mathrm{I}-5^{\mathrm{TM}}$ $2 \times$ High-Fidelity Master Mix (MCLAB, San Francisco, CA, USA), $1 \mu \mathrm{L}$ (2 pmol) of each primer, and $9.5 \mu \mathrm{L}$ ultra-pure and sterile water. The PCR was cycled at $98{ }^{\circ} \mathrm{C}$ for $2 \mathrm{~min}$, followed by 35 cycles of $98^{\circ} \mathrm{C}$ for $10 \mathrm{~s}, 57^{\circ} \mathrm{C}$ for $15 \mathrm{~s}$, and $72{ }^{\circ} \mathrm{C}$ for $80 \mathrm{~s}$, with a final cycle of $72{ }^{\circ} \mathrm{C}$ for $5 \mathrm{~min}$.

\section{Results}

After quality control, we obtained 16,745,104 variants from the paired-end sequencing. The significance threshold was set at 8.52. GWAS results showed that a genome region on chromosome 1 from $50.93 \mathrm{Mb}$ to $51.12 \mathrm{Mb}$ exceeded the significant threshold (Figure 2). This region harbors 15 genes, and the SOX10 gene is the only one functionally related to feather pigmentation [20]. We therefore, assumed that SOX10 was the gene responsible for LY plumage colour variation. We then extracted variants located within the SOX10 gene to predict their effects. However, none of the variants in SOX10 were significantly related to plumage colour. Instead, our results showed that the significant variation is distributed around the genomic region $51.05 \mathrm{Mb}$ to $51.09 \mathrm{Mb}$, indicating that there could be complex genome structural variation in this region.

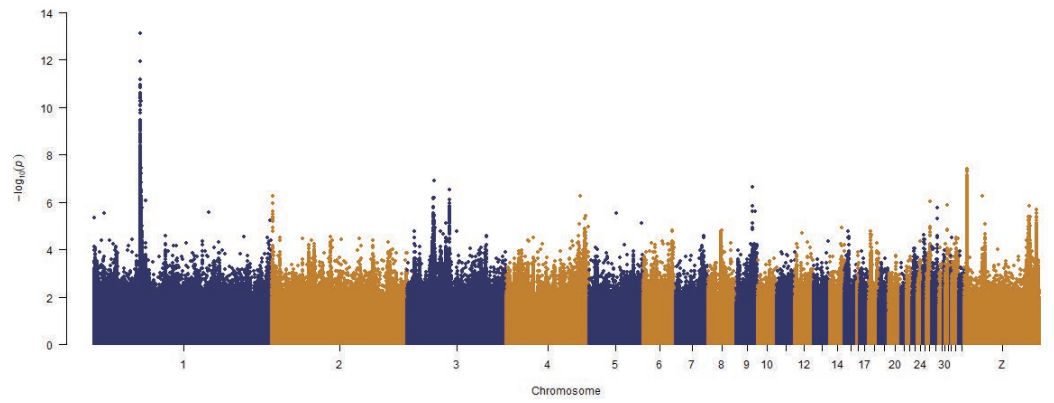

Figure 2. Genome-wide association analysis (GWAS) between DR and LY chickens. The horizontal axis represents the chromosome and the position, and vertical axis represents the negative logarithm of the unadjusted $p$-value for each SNP.

In order to identify the causative variant, we randomly selected 10 individuals for LY and DR respectively, and merged the sequencing data into a single file. We then mapped them to chromosome 1 , and calculated the sequencing coverage for each base. We found that the coverage in DR chickens at $51.03 \mathrm{Mb}$ to $51.04 \mathrm{Mb}$ was higher than that of $\mathrm{LY}$ chickens (Figure 3a). This suggested that there is a duplication in DR chickens or a deletion in LY chickens. We therefore extracted the insertion length of paired-end reads to identify the variant type, and found that the insertion length of some reads in LY chickens was longer than $7 \mathrm{~kb}$ while the insert length in DR chickens was under $1000 \mathrm{bp}$ (Figure 3b,c). 

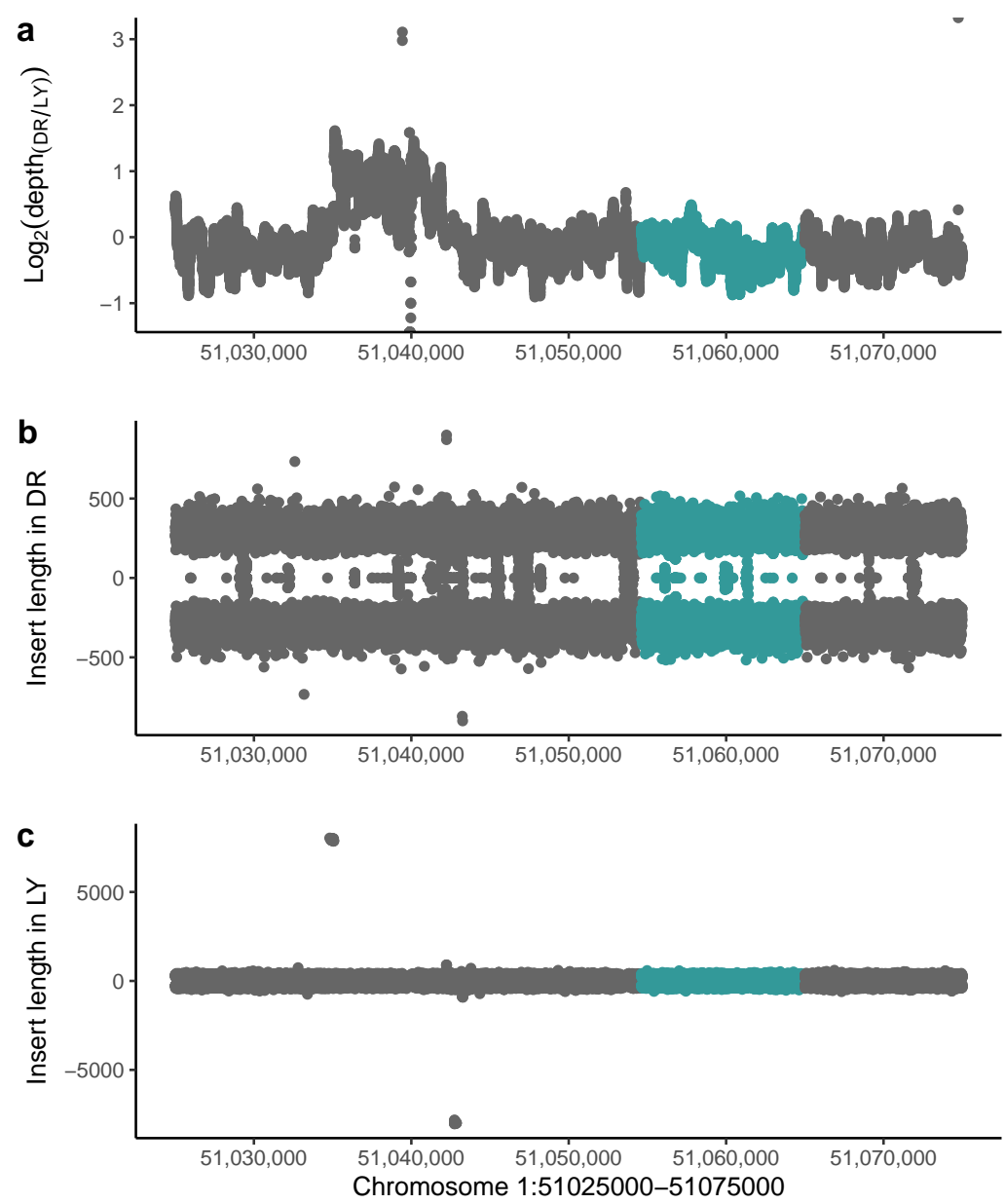

Figure 3. Sequencing depth and insert length showing LY chickens carrying a deletion, green dots represent the SOX10 gene. (a) The logarithm of sequencing depth ratio by base pair. It shows that the sequencing depth of DR chickens upstream of the SOX10 gene is higher than in LY chickens, indicating that that is a structure variant. (b) The insertion length of the paired reads in DR chickens, were all in the normal range. (c) The insertion length of the paired reads in LY chickens. The length showing part of the read insertion length is significantly higher than normal range, suggesting that the LY chickens carries a deletion upstream of the SOX10 gene.

In order to identify the breakpoint accurately, we designed primers to amplify the deletion region. The PCR results showed that all LY chickens are homozygous for the deletion while DR chickens are heterozygous for the deletion or homozygous for wild type, which suggested that LY is a recessive trait. We then sequenced the PCR product and Blasted the sequence against the chicken genome (GRCg6a). We found the genome region from $51,035,106 \mathrm{bp}$ to $51,042,744 \mathrm{bp}$ is missing in LY chickens, with this region showing a novel $10 \mathrm{bp}$ insertion (GGTGCGGTGA). Gunnarson et al. (2011) identified an upstream $8.3 \mathrm{~kb}$ deletion of SOX10 which causes dark brown plumage in red jungle fowl. The deletion in our study had similar genomic position and length to the previous study, and the two deletions showed the same $10 \mathrm{bp}$ insertion [20]. In order to verify the exact length of the deletion in our study, we PCR amplified the genomic region on chromosome 1 from 51,035,006 bp to 51,043,744 bp. The assembled sequence showed that the deletion is $7638 \mathrm{bp}$ in length.

\section{Discussion}

In this study, we identified a $7.6 \mathrm{~kb}$ non-coding deletion near the SOX10 gene as the cause of the LY phenotype. Gunnarson et al. (2011) found that an upstream $8.3 \mathrm{~kb}$ deletion of SOX10 gene caused the DB (dark brown) phenotype in chicken, by compare the 
flanking sequence we confirmed that we have reported same variant [20]. This coordinate difference comes from improved genome sequencing and assembly as Gunnarson's study used Galgal3 as the reference genome. Further analysis found that Galgal3 harbours an excessive N-gap region $30 \mathrm{~kb}$ upstream of the SOX10 gene, while Galgal6 showed complete sequence at this gap. Previous studies have shown that many genes are involved in the eumelanin pathway, such as MC1R, MITF, SOX10, PAX3 etc. [27]. The SOX10 gene activates the MITF gene by regulating the expression of eumelanin, and has great impact on the neural crest development. The long-range non-coding mutations of SOX10 have been reported in many species. Domyan et.al(2014) found that SOX10 deletion is related to recessive red in pigeons [28], A SOX10 upstream noncoding deletion in transgenic mice were characterized by the near complete absence of skin pigment [29], indicating that the deletion harbours a transcriptional enhancer, with this hypothesis demonstrated in a later study [30].

Many studies have shown that there are a large number of genes controlling feather colour in the chicken genome, with different mutation combinations causing different phenotypes. The dominant white allele $(I)$ in $W L$ is exclusively associated with a $9 \mathrm{bp}$ insertion in exon 10 of the PMEL17 gene [19]. Gunnarsson et al.(2007) reported that the SLC45A2 gene on chromosome $\mathrm{Z}$ is associated with $S * S$ (silver), $S * N$ (wild type/gold), and $S * A L$ (sex-linked imperfect albinism) alleles in chickens [16], and cause a specific inhibition of dominant white allele $(I)$. In our WL-RIR cross population, the dominant white gene, I, was inhibited in females; while all the male chickens show dominant white plumage. The most likely allele combinations are that WL birds harbored - / Del (SOX10), I/I (PMEL17), and $Z^{S * S} / \mathrm{W}$ (SLC45A2) alleles; RIR birds harbored - / Del (SOX10), i/i (PMEL17), and $Z^{S^{*} N} / Z^{S * N}$ (SLC45A2) alleles; the male F1 generation harbored $-/-, I / i$, and $\mathrm{Z}^{S * S} / \mathrm{Z}^{S * N}$ alleles; the LY females harbored $\mathrm{Del} / \mathrm{Del}, I / I$, and $\mathrm{Z}^{S * N} / \mathrm{W}$ alleles; and the DR females harbored $W t /-, I / i$, and $Z^{S * N} / \mathrm{W}$ alleles (Figure 4).

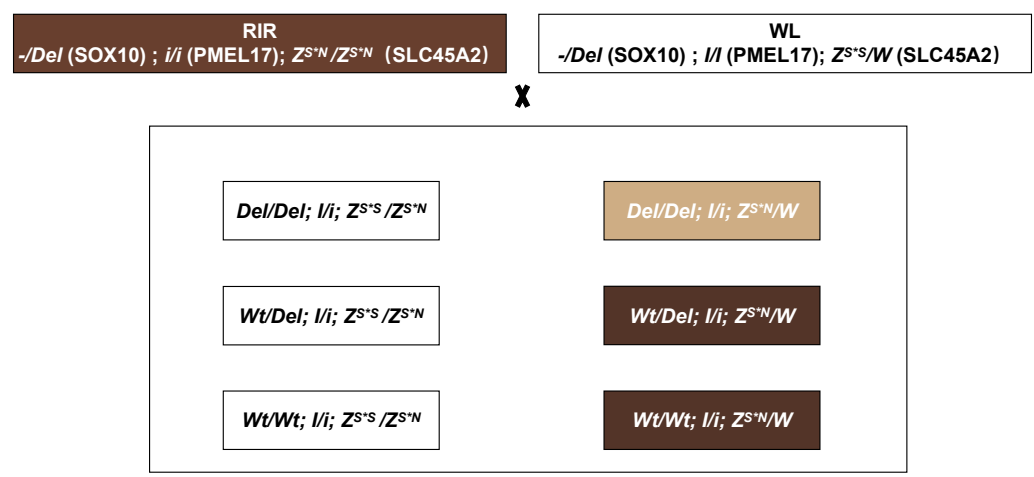

Figure 4. Del represents the SOX10 upstream deletion, $I$ and $i$ represent dominant white allelic, $Z^{S * S}$ represent Silver $(S * S)$ allelic, $Z^{S * N}$ represent wild type $(S * N)$ allelic. Colour in the box represent the plumage colour.

Author Contributions: Methodology, T.Z. and X.Z.; resources, H.W., H.L. and S.P.; writing—original draft preparation, T.Z. and M.L.; writing-review and editing, L.Q. and Z.N.; funding acquisition, Y.C., X.L., W.F., K.L., J.Z., L.W. and W.Y. All authors have read and agreed to the published version of the manuscript.

Funding: This work was supported by Beijing Innovation Team of the Modern Agro-industry Technology Research System (BAIC04-2021).

Institutional Review Board Statement: Sample collection was performed using strict protocols approved by the Animal Welfare Committee of China Agricultural University (permit XK622). The experimental procedures with ducks were performed according to the Guidelines for Experimental Animals established by the Ministry of Science and Technology (Beijing, China).

Informed Consent Statement: Not applicable. 
Data Availability Statement: The datasets generated for this study can be found in the NCBI (https:/ / www.ncbi.nlm.nih.gov/ accessed on 27 April 2016) under BioProject ID PRJNA723465.

Acknowledgments: In this section you can acknowledge any support given which is not covered by the author contribution or funding sections. This may include administrative and technical support, or donations in kind (e.g., materials used for experiments).

Conflicts of Interest: The authors declare no conflict of interest.

\section{Abbreviations}

The following abbreviations are used in this manuscript:

$\begin{array}{ll}\text { DR } & \text { dark red } \\ \text { LY } & \text { light yellow } \\ \text { GWAS } & \text { genome wide association study } \\ \text { RIR } & \text { Rhode Island Red } \\ \text { WL } & \text { White Leghorn }\end{array}$

\section{References}

1. Hillel, J.; Groenen, M.; Tixier-Boichard, M.; Korol, A.; David, L.; Kirzhner, V.; Burke, T.; Barre-Dirie, A.; Crooijmans, R.; Elo, K.; et al. Biodiversity of 52 chicken populations assessed by microsatellite typing of DNA pools. Genet. Sel. Evol. GSE 2003, 35, 533-557. [CrossRef] [PubMed]

2. Xunhe, H.; Wu, Y.J.; Miao, Y.W.; Peng, M.S.; Chen, X.; He, D.L.; Suwannapoom, C.; Du, B.W.; Li, X.Y.; Weng, Z.X.; et al. Was chicken domesticated in northern China? New evidence from mitochondrial genomes. Sci. Bull. 2018, 63, 743-746. [CrossRef]

3. Moiseyeva, I.G.; Romanov, M.N.; Nikiforov, A.A.; Sevastyanova, A.A.; Semyenova, S.K. Evolutionary relationships of Red Jungle Fowl and chicken breeds. Genet. Sel. Evol. 2003, 35, 403. [CrossRef]

4. Wang, M.S.; Thakur, M.; Peng, M.S.; Jiang, Y.; Frantz, L.A.F.; Li, M.; Zhang, J.J.; Wang, S.; Peters, J.; Otecko, N.O.; et al. 863 genomes reveal the origin and domestication of chicken. Cell Res. 2020, 30, 693-701. [CrossRef] [PubMed]

5. Agnvall, B.; Bélteky, J.; Jensen, P. Brain size is reduced by selection for tameness in Red Junglefowl-correlated effects in vital organs. Sci. Rep. 2017, 7, 1-7. [CrossRef]

6. Katajamaa, R.; Jensen, P. Tameness correlates with domestication related traits in a Red Junglefowl intercross. Genes Brain Behav. 2021, 20, e12704. [CrossRef]

7. Sutherland, D.A.; Honaker, C.; Dorshorst, B.; Andersson, L.; Brisbin, I.; Siegel, P. Growth patterns for three generations of an intercross between red junglefowl and chickens selected for low body weight. J. Anim. Breed. Genet. 2018, 135. [CrossRef]

8. Saino, N.; Romano, M.; Rubolini, D.; Teplitsky, C.; Ambrosini, R.; Caprioli, M.; Canova, L.; Wakamatsu, K. Sexual Dimorphism in Melanin Pigmentation, Feather Coloration and Its Heritability in the Barn Swallow (Hirundo rustica). PLoS ONE 2013, 8, e58024. [CrossRef]

9. Stoddard, M.C.; Prum, R.O. How colorful are birds? Evolution of the avian plumage color gamut. Behav. Ecol. 2011, 22, 1042-1052. [CrossRef]

10. Aspengren, S.; Sköld, H.N.; Quiroga, G.; Mårtensson, L.; Wallin, M. Noradrenaline- and Melatonin-Mediated Regulation of Pigment Aggregation in Fish Melanophores. Pigment. Cell Res. 2003, 16, 59-64. [CrossRef]

11. Hearing, V.J.; Tsukamoto, K.; Urabe, K.; Kameyama, K.; Montague, P.M.; Jackson, I.j. Functional Properties of Cloned Melanogenic Proteins. Pigment. Cell Res. 1992, 5, 264-270. [CrossRef]

12. Fogelholm, J.; Henriksen, R.; Höglund, A.; Huq, N.; Johnsson, M.; Lenz, R.; Jensen, P.; Wright, D. CREBBP and WDR 24 Identified as Candidate Genes for Quantitative Variation in Red-Brown Plumage Colouration in the Chicken. Sci. Rep. 2020, $10,1161$. [CrossRef]

13. Huang, T.; Pu, Y.; Song, C.; Sheng, Z.; Hu, X. A quantitative trait locus on chromosome 2 was identified that accounts for a substantial proportion of phenotypic variance of the yellow plumage color in chicken. Poult. Sci. 2020, 99, 2902-2910. [CrossRef] [PubMed]

14. Li, J.; Bed Hom, B.; Marthey, S.; Valade, M.; Dureux, A.; Moroldo, M.; Péchoux, C.; Coville, J.L.; Gourichon, D.; Vieaud, A.; et al. A missense mutation in TYRP1 causes the chocolate plumage color in chicken and alters melanosome structure. Pigment. Cell Melanoma Res. 2019, 32, 381-390. [CrossRef] [PubMed]

15. Kerje, S.; Sharma, P.; Gunnarsson, U.; Kim, H.; Bagchi, S.; Fredriksson, R.; Schütz, K.; Jensen, P.; von Heijne, G.; Okimoto, R.; et al. The Dominant white, Dun and Smoky Color Variants in Chicken Are Associated With Insertion/Deletion Polymorphisms in the PMEL17 GeneSequence data from this article have been deposited with the EMBL/GenBank Data Libraries under accession nos. AY636124, AY636125, AY636126, AY636127, AY636128, AY636129. Genetics 2004, 168, 1507-1518. [CrossRef]

16. Gunnarsson, U.; Hellstrom, A.R.; Tixier-Boichard, M.; Minvielle, F.; Bed’hom, B.; Ito, S.; Jensen, P.; Rattink, A.; Vereijken, A.; Andersson, L. Mutations in SLC45A2 Cause Plumage Color Variation in Chicken and Japanese Quail. Genetics 2007, 175, 867-877. [CrossRef] [PubMed] 
17. Araguas, R.M.; Sanz, N.; Viñas, J.; Vidal, O. MC1R polymorphism associated with plumage color variations in Coturnix chinensis. Anim. Genet. 2018, 49, 475-477. [CrossRef] [PubMed]

18. Guo, X.L.; Li, X.L.; Li, Y.; Gu, Z.L.; Zheng, C.S.; Wei, Z.H.; Wang, J.S.; Zhou, R.Y.; Li, L.H.; Zheng, H.Q. Genetic variation of chicken MC1R gene in different plumage colour populations. Br. Poult. Sci. 2010, 51, 734-739. [CrossRef]

19. Kerje, S.; Lind, J.; Schütz, K.; Jensen, P.; Andersson, L. Melanocortin 1-receptor (MC1R) mutations are associated with plumage colour in chicken. Anim. Genet. 2003, 34, 241-248. [CrossRef]

20. Gunnarsson, U.; Kerje, S.; Bed'Hom, B.; Sahlqvist, A.S.; Ekwall, O.; Tixier-Boichard, M.; Kampe, O.; Andersson, L. The Dark brown plumage color in chickens is caused by an 8.3-kb deletion upstream of SOX10. Pigment. Cell Melanoma Res. 2011, 24, 268-274. [CrossRef]

21. Schwochow Thalmann, D.; Ring, H.; Sundström, E.; Cao, X.; Larsson, M.; Kerje, S.; Höglund, A.; Fogelholm, J.; Wright, D.; Jemth, P.; et al. The evolution of Sex-linked barring alleles in chickens involves both regulatory and coding changes in CDKN2A. PLoS Genet. 2017, 13, 1-22. [CrossRef] [PubMed]

22. Chen, S.; Zhou, Y.; Chen, Y.; Gu, J. fastp: an ultra-fast all-in-one FASTQ preprocessor. Bioinformatics 2018, 34, i884-i890. [CrossRef] [PubMed]

23. Li, H.; Durbin, R. Fast and accurate short read alignment with Burrows-Wheeler transform. Bioinformatics 2009, 25, 1754-1760. [CrossRef] [PubMed]

24. Van der Auwera, G.A.; Carneiro, M.O.; Hartl, C.; Poplin, R.; Del Angel, G.; Levy-Moonshine, A.; Jordan, T.; Shakir, K.; Roazen, D.; Thibault, J.; et al. From FastQ Data to High-Confidence Variant Calls: The Genome Analysis Toolkit Best Practices Pipeline. Curr. Protoc. Bioinform. 2013, 43, 11.10.1-11.10.33. [CrossRef]

25. Danecek, P.; Auton, A.; Abecasis, G.; Albers, C.A.; Banks, E.; DePristo, M.A.; Handsaker, R.E.; Lunter, G.; Marth, G.T.; Sherry, S.T.; et al. The variant call format and VCFtools. Bioinformatics 2011, 27, 2156-2158. [CrossRef]

26. Purcell, S.; Neale, B.; Todd-Brown, K.; Thomas, L.; Ferreira, M.A.R.; Bender, D.; Maller, J.; Sklar, P.; de Bakker, P.I.W.; Daly, M.J.; et al. PLINK: A Tool Set for Whole-Genome Association and Population-Based Linkage Analyses. Am. J. Hum. Genet. 2007, 81, 559-575. [CrossRef]

27. Lin, J.; Fisher, D. Melanocyte biology and skin pigmentation. Nature 2007, 445, 843-850. [CrossRef]

28. Domyan, E.T.; Guernsey, M.W.; Kronenberg, Z.; Krishnan, S.; Boissy, R.E.; Vickrey, A.I.; Rodgers, C.; Cassidy, P.; Leachman, S.A.; Fondon, J.W.; et al. Epistatic and Combinatorial Effects of Pigmentary Gene Mutations in the Domestic Pigeon. Curr. Biol. 2014, 24, 459-464. [CrossRef]

29. Antonellis, A.; Bennett, W.R.; Menheniott, T.R.; Prasad, A.B.; Lee-Lin, S.Q.; Green, E.D.; Paisley, D.; Kelsh, R.N.; Pavan, W.J.; Ward Andrew, N.C.S.P. Deletion of long-range sequences at Sox10 compromises developmental expression in a mouse model of Waardenburg-Shah (WS4) syndrome. Hum. Mol. Genet. 2005, 15, 259-271. [CrossRef]

30. Antonellis, A.; Huynh, J.; Lee-Lin, S.Q.; Vinton, R.; Renaud, G.; Loftus, S.; Elliot, G.; Wolfsberg, T.; Green, E.; Mccallion, A.; et al. Identification of Neural Crest and Glial Enhancers at the Mouse Sox10 Locus through Transgenesis in Zebrafish. PLoS Genet. 2008, 4, e1000174. [CrossRef] 